\title{
Analysis of the Physiological and Metabolic Responses between Two Types of Training in Wistar Rats
}

\section{Análise das respostas fisiológicas e metabólicas entre dois tipos de treinamento em ratos wistar}

\author{
Waleska dos Santos \\ (D) https://orcid.org/0000-0003-3319-3876 \\ Jymmys Lopes dos Santos ${ }^{1}$ \\ (D) https://orcid.org/0000-0003-1433-2041 \\ Anderson Carlos Marçal ${ }^{1}$ \\ (D) https://orcid.org/0000-0001-7869-2922 \\ Felipe José Aidar \\ (D) https://orcid.org/0000-0001-7378-4529 \\ Lúcio Marques Vieira Souza ${ }^{1}$ \\ (D) https://orcid.org/0000-0002-5721-0725 \\ Silvan Silva de Araújo $0^{1}$ \\ (D) https://orcid.org/0000-0003-2469-1304
}

Abstract -This study analyzed the responses of 24 sessions of High Intensity Interval Training (HIIT) and Continuous Moderate (CM) on tissue damage, oxidative stress and glycemic profile of rats in liquid medium. Twenty-four Wistar rats participated, divided into three groups: sedentary (GSED), the one who performed the HIIT (GHIIT) and the one who performed the CM (GCM). Performed three times a week alternately for 8 weeks, and the GHIIT performed 20 seconds of exercise for 10 rest. The CM was a moderate intensity swim. GHIIT increased creatine kinase compared to GSED (GSED: 140.40 + 35.48 U / I; GHIIT: $442.60+8.35 \mathrm{U} / \mathrm{I} ; \mathrm{p}=0.0008$, representing a percentage increase of 215.24); lactate dehydrogenase was increased in GHIIT and GCM compared to GSED (GSED: $112.8+28.08$ U / I; GHIIT: $250.9+70.67$ U / I, a percentage increase of 122.42; GCM: $241.8+100.70 \mathrm{U}$ / I, with a percentage increase $114.36 ; \mathrm{p}=0.006$ ), in contrast, GHIIT increased non-oxidized liver sulfhydryls compared to GCM (GHIIT: $498.70+214.30 \mathrm{nmol} / \mathrm{ml}$; GCM: 270.50 + $104.40 \mathrm{nmol} / \mathrm{ml}$, the percentage change was $84.36 ; \mathrm{p}=0.03)$. There was greater glycemic maintenance in the GCM ( $\mathrm{p}=0.0002)$. It is concluded that the protocols of HIIT and CM, of this study, point to a possible tissue injury, in contrast, HIIT develops the adaptive capacity of the hepatic antioxidant system and the CM promotes greater glycemic support.

Key words: Biomarkers; Blood glucose; Exercise; High intensity interval training; Oxidative stress.

Resumo - Este estudo analisou as respostas de 24 sessöes de High Intensity Interval Training (HIIT) e Contínuo Moderado (CM) sobre a lesão tecidual, estresse oxidativo e perfil glicêmico de ratos em meio líquido. Participaram 24 ratos Wistar, divididos em três grupos: sedentário (GSED), o que fezo o HIIT (GHIIT) e o que executou o CM (GCM). Realizados três vezes semanais alternadamente por 8 semanas, sendo que o GHIIT executou 20 segundos de exercicio por 10 de descanso. O CM foi um nado de intensidade moderada. O GHIIT aumentou a creatina quinase em relação ao GSED (GSED: $140.40 \pm 35.48$ U/I; GHIIT: $442.60 \pm 8.35$ U/I; $p=0.0008$, representando um aumento percentual de 215.24); a lactato desidrogenase foi aumentada no GHIIT e GCM em relação ao GSED (GSED: 112.8 28.08 U/I; GHIIT: $250.9 \pm 70.67$ U/I, um aumento percentual de 122.42; GCM: $241.8 \pm$ 100.70 U/I, com aumento percentual de 114.36; $p=0.006)$, em contrapartida, o GHIIT aumentou as sulfidrilas hepáticas não oxidadas em relação ao GCM (GHIIT: $498.70 \pm 214.30 \mathrm{nmol} / \mathrm{ml}$; GCM: $270.50 \pm 104.40 \mathrm{nmol} / \mathrm{ml}$, a variação percentual foi de 84.36; $p=0.03)$. Houve maior manutenção glicêmica no GCM (p=0.0002). Conclui-se que os protocolos de HIIT e CM, deste estudo, apontam para a uma possivel lesão tecidual, em contrapartida, o HIIT desenvolve a capacidade de adaptação do sistema antioxidante hepático e o CM promove uma sustentação glicêmica maior.

Palavras-chave: Biomarcadores; Estresse oxidativo; Exercício; Glicemia; Treinamento intervalado de alta intensidade.
1 Federal University of Sergipe. Graduate Program in Physical Education. São Cristovão, SE. Brazil.

Received: May 24, 2020 Accepted: October 20, 2020

How to cite this article Santos W, Santos JL, Marçal AC, Aidar FJ, Souza LMV, Araújo SS. Análise das Respostas Fisiológicas e Metabólicas entre Dois Tipos de Treinamento em Ratos Wistar. Rev Bras Cineantropom Desempenho Hum 2020, 22:e74189. DOl: http://dx.doi.org/10.1590/19800037.2020v22e74189

Copyright: This work is licensed under a Creative Commons Attribution 4.0 International License. 


\section{INTRODUCTION}

High Intensity Intervaled Training (HIIT), despite existing in the early twentieth century, has been the subject of much research and has attracted many followers, to the point of being in the current third fitness position worldwide $^{1 .}$ It consists of a training that mixes intervals of high intensity exercises with intervals of recovery, which can be active or passive. It has a maximum intensity, supramaximal, usually performed from $80 \%$ of the Maximum Heart Rate (FCM); active recovery intervals can be performed with intensity below the main exercise. HIIT can be short term (up to six weeks) or long term (up to 12 weeks).

The Continuous Training (CT) is characterized by performing the exercise without pause from start to finish. It is also known as endurance training. It is based on exercises typically of a cyclical nature, whose intensity is generally low to moderate, that is, below the anaerobic threshold.

Both trainings provide benefits, such as improving physical fitness, promoting cardioprotective effects ${ }^{2}$. Especially the Continuous training of Moderate intensity $(\mathrm{CM})$ makes the lipolysis process more potent, improves the rate of glycemia ${ }^{3}$, on the other hand, the interval training promotes a greater oxidation of lipids ${ }^{3}$ among other effects.

However, in parallel to these trainings, physical stress is present, which can cause tissue damage and oxidative stress. Therefore, the estimation of these events becomes necessary and possible through the analysis of their biomarkers. Thus, as the analysis of the profile of some energetic substrates, through the analysis of the glycemic profile, complements the investigation of these trainings.

Several studies ${ }^{4-7}$ proposed to study HIIT and CM and their relationship with tissue damage and oxidative stress, however, using different protocols from the present study. Thus, there is still a scientific gap, that is, it is not known whether the HIIT and the CM configured in eight weeks, with a frequency of three times a week, will have a harmful response to the organism; and how is the glycemic profile involving both exercises.

Thus, the general objective of this research was to compare the physiological and metabolic responses between two training models, the high intensity interval and the moderate continuous, in wistar rats. The specific objectives were: to assess the effects of HIIT and CM on tissue injury biomarkers (creatine kinase [CK], lactate dehydrogenase [LDH], alanine aminotransferase $[\mathrm{ALT}]$ and aspartate aminotransferase [AST]), and oxidative damage (malondialdehyde [MDA], sulfhydryl [SH], Urate); evaluate the effects of HIIT and CM on a metabolic parameter, the glycemic profile.

\section{METHOD}

\section{Sample}

Twenty-four rats of the species Rattus novergicus and Wistar lineage were used, as this quantity is sufficient to obtain results considering that studies 
have already used this sample number ${ }^{5,7}$, and were randomly distributed in three experimental groups: the GSED, group that did not physical exercise, that is, sedentary; GHIIT, group that performed High Intensity Interval Training and GCM, group that performed Continuous training of Moderate intensity. All with an average body mass of $275.33 \mathrm{~g}$ and an initial age of 60 days. This study was approved by the Ethics and Animal Research Committee of the Federal University of Sergipe under protocol 60/2017.

\section{Initial Procedures}

\section{- Adaptation to the Liquid Environment}

The rats were adapted according to the protocol proposed by Marangon et al. ${ }^{8}$ with modifications. With a duration of 15 uninterrupted days, in a cylindrical tank with a capacity of $157 \mathrm{~L}$, with a smooth surface, measuring $50 \mathrm{~cm}$ in diameter by $80 \mathrm{~cm}$ in depth and the water temperature to $31+/-1 \mathrm{C}$, in order to reduce the animal stress without promoting prior physiological adaptations, the water depth was $70 \mathrm{~cm}$. The groups made the adaptation always at the same time.

The GSED remained in shallow water for 15 minutes during the 15 days without overloading the body. The group that did the High Intensity Interval Training (GHIIT) and the group that did the Continuous Moderate Training (GCM) were immersed in shallow water, 15 minutes in the first three days; from the 4th day, they swam in deep water for 2 minutes, with an increase of two minutes each day until reaching the 10th day of adaptation; on the 11th day they swam in deep water for five minutes with an overload of $3 \%$ based on their body mass, tied to the back, with increases of five minutes each day until the 15 th day.

\section{- Determination of the glycemic threshold of exercises}

The determination of the glycemic threshold (LG) was made in all groups. It was a low-cost alternative, therefore more accessible, and referred to as an alternative for determining the anaerobic threshold ${ }^{9-11}$ because, by visual inspection of the inflection point of the glycemic curve, the LG used to determine the load intensity. This threshold was assessed 24 hours after the adaptation period to the liquid medium.

The LG determination protocol was adapted from the Lactate Threshold determination protocol ${ }^{12}$. And it consisted of a progressive load test making 6 consecutive swimming stages, in the same tank in which the adaptation was made. Each stage lasted 5 minutes, and the rats carried loads tied to the back equivalent to $3.5 \%, 4 \%, 4.5 \%, 5 \%, 5.5 \%, 6 \%$ of body mass, respectively from the first to the sixth stage. The adopted exhaustion criterion was submersion of the animal at $10 \mathrm{~cm}$ for more than 10 seconds, and inability to return to the water surface, associated with the loss of symmetrical movements of displacement.

\section{Training Protocols}

The sedentary group (GSED) did not do training for 8 weeks, being kept 
uninterrupted in their respective. The GSED was used to control the parameters analyzed in the trained groups.

\section{HIIT}

Before performing the High Intensity Interval Training (HIIT), a maximum test was performed, and it was performed 24 hours after the determination of the Glycemic Threshold (LG). The maximum test was adapted from Pimenta et al. ${ }^{13}$ and had the following characteristics: the maximum number of sets (of 20 seconds of exercise for 10 of rest, using $10 \%$ overload based on body mass), which the animal was able to perform until exhaustion. The load used (10\%) determined a high intensity for the animal, being, therefore, above the anaerobic threshold.

The HIIT protocol was also adapted from Pimenta et $a 1 .{ }^{13}$ as shown in figure one. Each set consisted of 20 seconds of exercise, followed by 10 seconds of rest, with the aid of a timer program. After each training session, the rodents were dried and placed in their respective boxes. These loads accounted for 220 to $280 \%$ of the glycemic threshold.

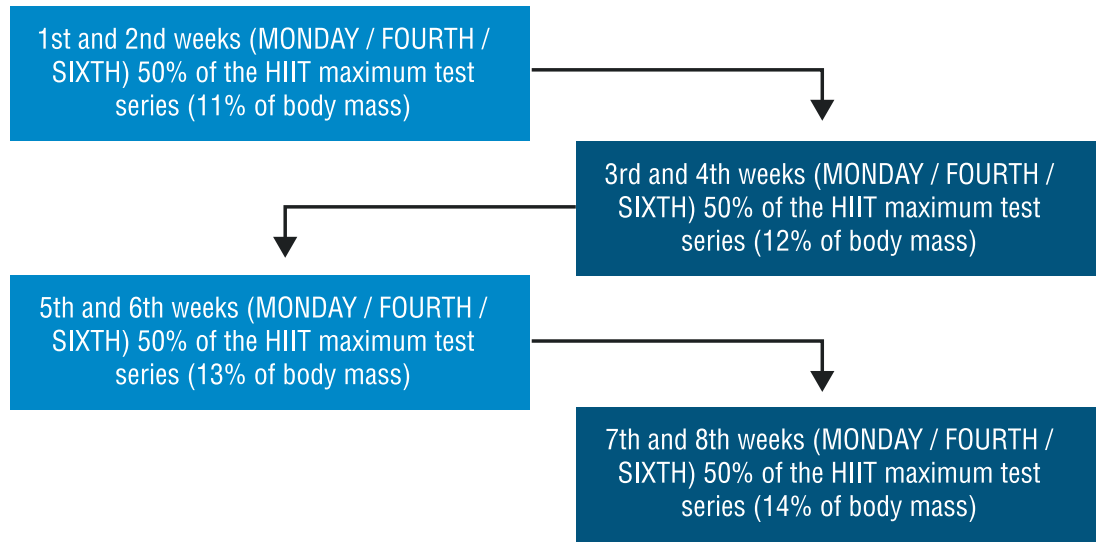

Figure 1: High Intensity Interval Training (HIIT) protocol (Pimenta et al., 2015).

\section{CIM}

Before the Continuous Moderate (CM) training, a maximum test was performed, performed 24 hours after the determination of the Glycemic Threshold (LG). And the criterion for determining exhaustion was the same as for the maximum HIIT test. The maximum $\mathrm{CM}$ test consisted of identifying the maximum duration of the swim until exhaustion, using a moderate overload, that is, below the LG. The CM protocol (figure two) respected the same principle as GHIIT, each animal using moderate overload, that is, slightly below the LG, totaling 24 sessions. This load represented an intensity corresponding to $90 \%$ of the glycemic threshold.

Each week the blood glucose of the three groups was measured for the analysis of the chronic glycemic profile of the animals. And before completing the interventions, that is, 24 hours before the 24th training day, the groups underwent a new assessment of the glycemic curve, using strips for glycemic testing, in the same way as before the interventions. 


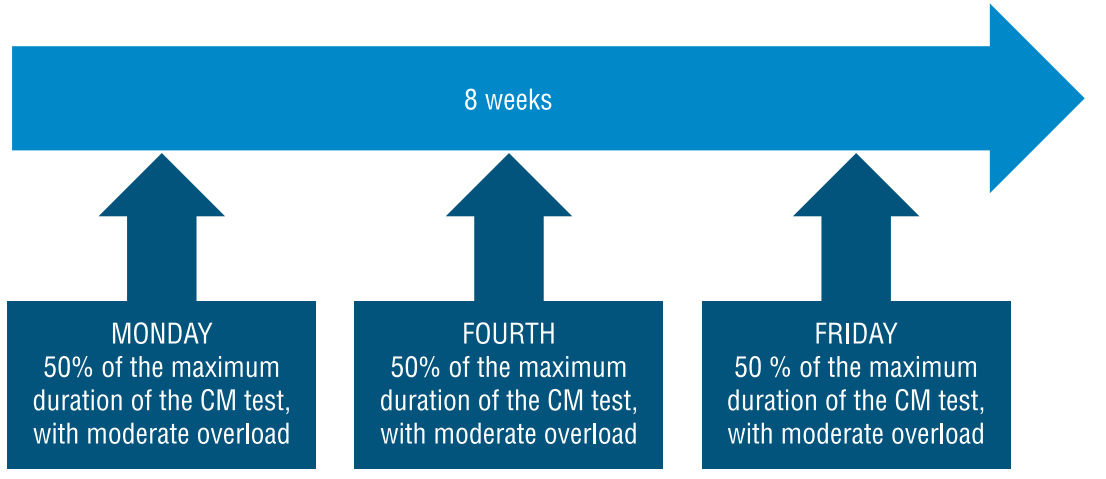

Figure 2: Continuous Moderate training protocol (CM) (adapted from Pimenta et al., 2015)

\section{Statistical procedure}

The sample normality test was performed using Brown-Forsythe. Kruskal Wallis was applied with Dunn's post-test to analyze tissue injury markers (creatine kinase, lactate dehydrogenase, and alanine aminotransferase); the one way anova with Tukey's post-test for aspartate aminotransferase and for the analysis of oxidative stress markers; a Two-way ANOVA of repeated measures for the analysis of weekly blood glucose and glycemic curve. Pearson's correlation was used to assess the correlations between all markers. The statistical software used was GraphPad Prism version 7.00 for Windows. Data were expressed as mean + standard deviation; the statistically significant values were considered as $\mathrm{p}<0.05$.

\section{RESULTS}

The main data referring to tissue injury regarding the mean and standard deviation of the groups: sedentary (GSED), High Intensity Interval Training (GHIIT) and Continuous Moderate (CM) are listed in table 1.

The power of the effect of the increase in CK in GHIIT represented by the glass delta, of 8.51. The magnitude of the increase in LDH in GHIIT in relation to GSED represented by the glass delta of 4.91. LDH in GCM in relation to GSED by glass delta, 4.59. And finally, the non-oxidized sulphiphiles increased in the GHIIT in relation to the GCM represented an effect power of 2.18 by the glass delta.

The SGOT / SGPT or AST / ALT ratio, which represents an indicator of liver damage, remained in the normal range $(0.7-1.44)$ in the groups.

Figure three shows a differentiation of weekly blood glucose between groups, with a predominance of glycemic increase in the GCM. As well as, intragroup changes were observed, with emphasis on the fourth week, which corresponded to half of the training period, and in which occurred, the glycemic drop in GHIIT and elevation in GCM, until finally, the three groups ended the training period with similar blood glucose. The effect size obtained was 0.14 , considered small. The Confidence Interval for GSED was $5.72-6.33 \mathrm{nmol} / \mathrm{ml}$ of glucose; for GHIIT it was 5.49-6.38 nmol / $\mathrm{ml}$ of glucose; for the GCM it was $6.10-6.69 \mathrm{nmol} / \mathrm{ml}$ of glucose. 
Table 1. Tissue injury markers: (Creatine Kinase (CK), Lactate Dehydrogenase (LDH), Alanine Aminotransferase (ALT), Aspartate Aminotransferase (AST), and Oxidative Stress.

\begin{tabular}{|c|c|c|c|c|c|c|c|}
\hline & $\begin{array}{c}\text { GSED }(n=8) \\
\text { Mean and SD }\end{array}$ & $\mathrm{Cl}$ & $\begin{array}{c}\text { GHIIT }(n=8) \\
\text { Mean and SD }\end{array}$ & $\mathrm{Cl}$ & $\begin{array}{c}\mathrm{GCM}(\mathrm{n}=8) \\
\text { Mean and SD }\end{array}$ & $\mathrm{Cl}$ & $p$ (value) \\
\hline CK $(\mathrm{U} / \mathrm{I})$ & $140.4 \pm 35.48$ & $58.07-250.4$ & $442.6 \pm 8.35^{a}$ & $147.9-747.3$ & $299.4 \pm 110.7$ & $206.8-392$ & 0.01 \\
\hline $\mathrm{LDH}(\mathrm{U} / \mathrm{I})$ & $112.8 \pm 28.08$ & $86.78-138.7$ & $250.9 \pm 70.67^{a}$ & $191.9-310$ & $241.8 \pm 100.7^{a}$ & $157.7-326$ & 0.006 \\
\hline $\operatorname{ALT}(\mathrm{U} / \mathrm{I})$ & $66.7 \pm 22.37$ & $31.1-102.3$ & $128.2 \pm 50.21$ & $65.85-190.5$ & $75.28 \pm 27.32$ & $52.18-98.37$ & 0.15 \\
\hline AST (U/I) & $71.35 \pm 6.7$ & $11-131.7$ & $111.4 \pm 30.3$ & $73.77-149$ & $76.84 \pm 11.12$ & $63.04-90.64$ & 0.05 \\
\hline AST/ALT(U/I) & 1.06 & & 0.86 & & 1.01 & & - \\
\hline $\begin{array}{l}\text { HEPÁTIC MDA } \\
\text { nmol Eq MDA/ mg tissue }\end{array}$ & $13.48 \pm 2.21$ & $9.95-17$ & $13.78 \pm 5.18$ & $9.44-18.11$ & $15.05 \pm 3.95$ & $11.75-18.36$ & 0.77 \\
\hline $\begin{array}{l}\text { CARDÍAC MDA } \\
\text { nmol Eq MDA/mg tissue }\end{array}$ & $6.07 \pm 0.37$ & $5.47-6.66$ & $6.49 \pm 2.58$ & $4.11-8.88$ & $7.98 \pm 1.24$ & $6.94-9.02$ & 0.16 \\
\hline $\begin{array}{l}\text { CALF MDA } \\
\text { nmol Eq MDA/ mg tissue }\end{array}$ & $6.15 \pm 0.55$ & $5.46-6.84$ & $6.35 \pm 1.03$ & $5.49-7.21$ & $6.5 \pm 1.27$ & $5.43-7.56$ & 0.84 \\
\hline $\begin{array}{l}\text { TOTALS SH } \\
\mathrm{nmol} / \mathrm{ml}\end{array}$ & $188.1 \pm 52.68$ & $122.7-253.5$ & $235.2 \pm 193.3$ & $32.37-438.1$ & $223.4 \pm 80.19$ & $149.2-297.6$ & 0.81 \\
\hline $\begin{array}{l}\text { HEPÁTIC SH } \\
\mathrm{nmol} / \mathrm{ml}\end{array}$ & $375.5 \pm 96.35$ & 274.4- 476.6 & $498.7+214.3^{b}$ & $319.5-677.9$ & $270.5 \pm 104.4$ & $174-367$ & 0.03 \\
\hline $\begin{array}{l}\text { CARDÍAC SH } \\
\mathrm{nmol} / \mathrm{ml}\end{array}$ & $109.5 \pm 26.41$ & $67.49-151.5$ & $218.6 \pm 135.5$ & $105.3-331.9$ & $288.5 \pm 188$ & $131.3-445.7$ & 0.17 \\
\hline $\begin{array}{l}\text { CALF SH } \\
\mathrm{nmol} / \mathrm{ml}\end{array}$ & $323.4 \pm 167.4$ & $147.8-499.1$ & $260.2 \pm 219.3$ & 76.87- 443.6 & $312.8 \pm 171.5$ & $169.4-456.2$ & 0.79 \\
\hline $\begin{array}{l}\text { URATE } \\
\mathrm{md} / \mathrm{dl}\end{array}$ & $2.57 \pm 0.43$ & $2.04-3.11$ & $2.87 \pm 1.2$ & $1.86-3.87$ & $3.06 \pm 0.49$ & $2.65-3.47$ & 0.59 \\
\hline
\end{tabular}

Note: GSED = sedentary group; GHIIT = High Intensity Interval Training Group; GCM = Moderate Continuous group. CK = creatine kinase; $\mathrm{LDH}=$ lactate dehydrogenase; ALT = alanine aminotransferase; $\mathrm{AST}=$ aspartate amonotransferase. $\mathrm{MDA}=$ malondialdehyde; $\mathrm{SH}=$ sulfhydryls. $\mathrm{a}=$ difference between GSED. $\mathrm{b}=$ difference between GHIIT and GCM.

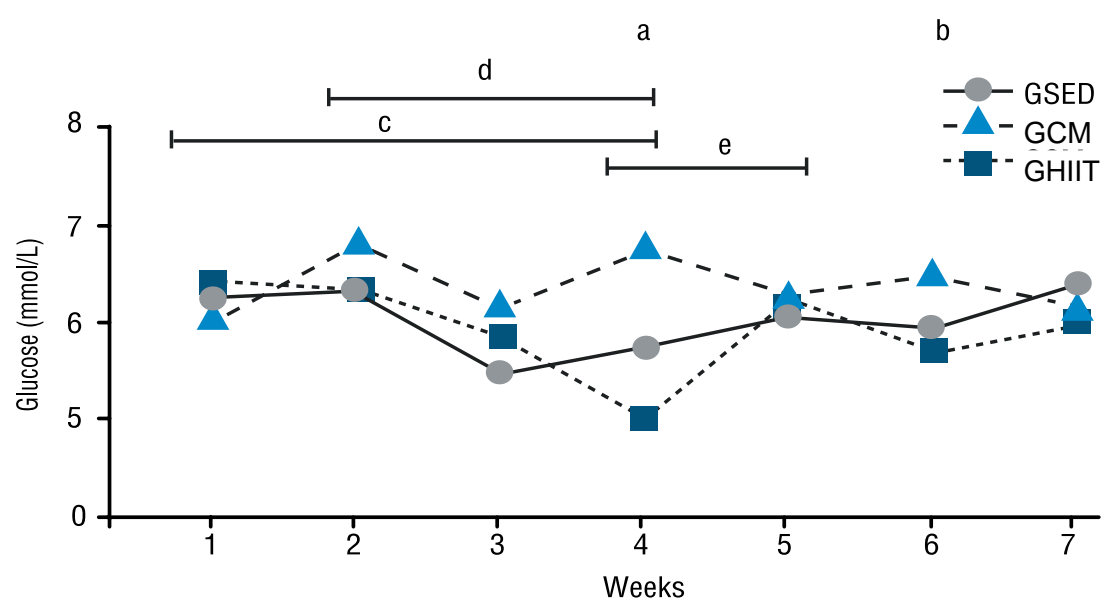

Figure 3: Weekly glycemia (GSED= sedentary group; GHIIT= HIIT group; GCM= Moderate Continuous group). $a=$ increased glycemia of GCM in relation to GHIIT and GSED; $b=$ increased glycemia of GCM in relation to GHIIT, according to $(F(2,137)=9.14 ; p=0.0002) ; c=$ difference between week 1 and week 4 of GHIIT; $d=$ difference between week 2 and 4 of GHIIT; $e=$ difference between week 4 and week 5 of the GHIIT, according $(F(6,137)=3.65, p=0.002)$.

\section{DISCUSSION}

The present study pointed to a possible acute muscle injury due to the increase in creatine kinase $(\mathrm{CK})$ in the group that performed the High Intensity Interval Training (GHIIT) in relation to the sedentary group (GSED), representing a percentage increase of 215.24. As well as, the 


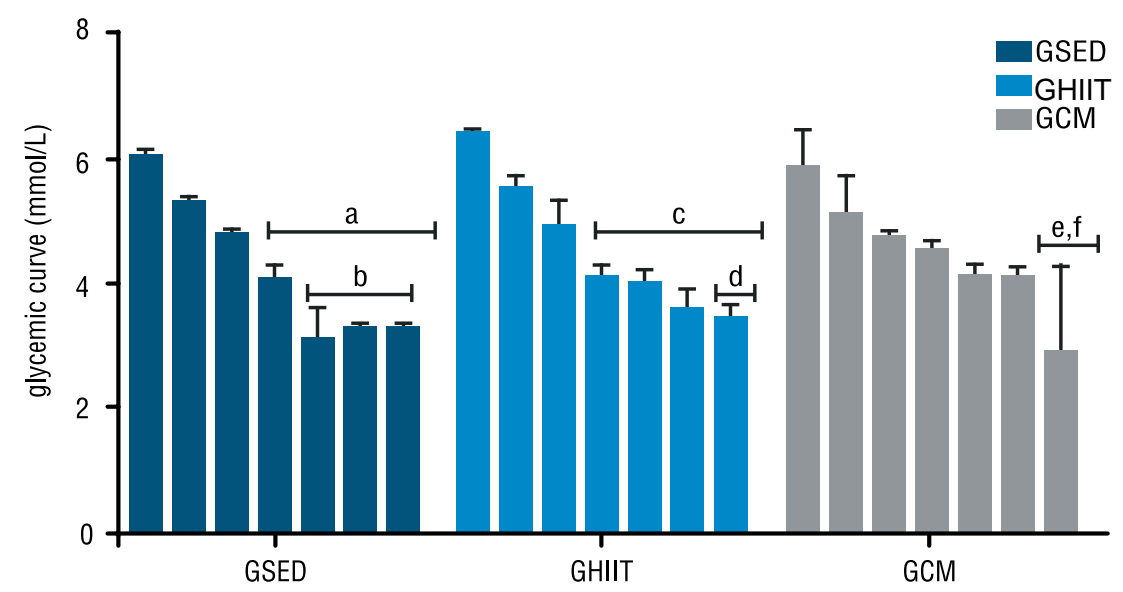

Figure 4: Glycemic curve composed of seven bars respectively from left to right corresponding to the beginning of the test until the sixth stage. (GSED = sedentary group; GHIIT = HIIT group; GCM = Moderate Continuous group); $\mathrm{a}=$ difference between the initial glycemia and the 3rd, 4th, 5th, and 6th stages; $b=$ difference between 1st stage glycemia and 4th, 5 th and 6th stages; $c=$ difference between the initial glycemia and the $3 \mathrm{rd}$, 4th, 5 th, and 6 th stages; $d=$ difference between the 1 st and 6 th stages; $\mathrm{e}=$ difference between the initial glycemia and the 6 th stage; $f=$ difference between the 1 st and 6 th stages; $F(6.6)=32.43 ; p<0.01$. There was no difference between the groups, according $(F(2,2)=1.84) ; p=0.35$.

increase of lactate dehydrogenase (LDH) in the groups that did the HIIT and the Continuous Moderate (GCM) (table 1) in relation to (GSED), a percentage increase of 122.42 (GHIIT); and a percentage increase 114.36 (GCM) however, there was no difference between the groups trained in this marker, which can suggest a better action of the antioxidant system throughout the training.

Dos Santos et al. ${ }^{5}$ used high intensity resistance training (three sets of 10 repetitions at $75 \%$ of $1 \mathrm{RM}$, using the squat modality in rats, for four weeks, three times a week) and found a similar response to the present study regarding CK and LDH. However, Souza ${ }^{7}$ who used HIIT with a similar protocol (14 daily swimming sessions lasting 20 seconds of exercise for 10 seconds of rest, for 12 consecutive days, with a $14 \%$ load based on body mass) did not demonstrate tissue damage, which suggests that HIIT on alternate days and performed over a longer period of time, may influence these markers of muscle injury, since skeletal muscle is a tissue that is in high demand during intense exercise.

Regarding aspartate aminotransferase (AST), which is found in muscle and liver as its main sources and is an acute phase enzyme, it was not altered in the trained groups of the present study (table 1). In accordance with the study by Souza ${ }^{7}$ described earlier. Teixeira et al. ${ }^{14}$ also found no change in this marker in high-intensity training (eight weeks, five times a week, making four sets of 10 jumps with one minute of rest, with overload tied to the animal of $25-55 \%$ of body mass).

In the case of oxidative stress, hepatic, cardiac and muscular malondialdehyde (MDA) did not differ between groups (table 1). Souza ${ }^{7}$ also found no oxidative damage due to HIIT with swimming for 12 sessions. Even Freitas et al. ${ }^{15}$ revealed that HIIT on a treadmill, six times during 6 weeks, at a higher frequency than the present study, reduced the concentration of 
this marker in the hippocampus, possibly due to the adaptive capacity of the antioxidant system.

Regarding moderate-intensity training, Pereira et al. ${ }^{16}$ in a study using moderate-intensity training with diabetic subjects on a treadmill, three times a week, for 12 weeks, for about 20 to 20 years. 60 minutes, they found that lipid peroxidation was reduced, a fact proven by reducing the MDA, without necessarily having an increase in the antioxidant system. In this way, the training of the present study in some way contributes to the containment of lipid peroxidation, which occurs with the excess of Reactive Oxygen Species (ROS), but which was regulated by the antioxidant system.

Still dealing with oxidative stress, the sulfhydryl groups $(\mathrm{SH})$ in the liver of GHIIT were increased (table 1), the percentage change was 84.36. And this increase can be explained by an action of self-regulation of the organism, in response to the formation of ROS's, that is, it increased the hepatic antioxidant defense, as well as it may have improved the endogenous antioxidant enzymes. The HIIT protocol with 12 consecutive sessions used by Souza ${ }^{7}$, on the other hand, did not change the total SH, possibly because it had a shorter period.

Moderate training seems to be beneficial in relation to oxidative stress ${ }^{17}$ because the moderate training protocol used by Tromm et al. ${ }^{17}$ on a treadmill with a weekly frequency of three times, for 8 weeks was effective to reduce oxidative damage and increase antioxidant defense in the liver and heart of mice. However, the $\mathrm{CM}$ of the present study reached concentrations of hepatic $\mathrm{SH}$ groups lower than HIIT, indicating that a differential to be observed is the training modality, which in this study was swimming, in addition, in the Tromm study there was no comparison between the CM and HIIT.

The work of Leite and Rombaldi ${ }^{18}$ compared eight weeks of intense training with rats (60 minutes divided into 2 periods of 30 minutes, in these 15 seconds were swimming and 15 seconds of rest, repeating this series 60 times, there was an interval of 10 minutes between the periods, using $10 \%$ overload based on body mass), with moderate continuous training (continuous swimming using 5\% overload of body mass for 60 minutes) and revealed that the anaerobic interval training caused an increase in urate concentrations. This data may indicate that long-term, high-intensity interval training can cause it to increase.

Regarding the analysis of the weekly glycemic profile and the glycemic curve, the results indicated that there was a glycemic change between the groups, as observed in figures four and five, revealing that the GCM had

\section{CONCLUSIONS}

Thus, we conclude the High Intensity Interval Training (HIIT) and the Continuous training of moderate intensity $(\mathrm{CM})$ performed 3 times a week for 8 weeks, based on the protocols of the present study, despite showing evidence of tissue injuries, with HIIT being predominantly at the muscle 
level, this training also demonstrates a better adaptation of the antioxidant defense system. CM, on the other hand, promotes greater glycemic stability, important to avoid hypoglycemics, on the other hand, or HIIT, proves to be effective in the greater use of the referred energy substrate, which is important to avoid hyperglycemic events.

Therefore, this research is innovative with no sense of indicating training parameters, as an example of term and duration, which affects tissue injuries and oxidative stress, as indicated by a glycemic profile used by users who use training that can use both as a hypoglycemia.

A limitation of the present study was the failure to measure hormones that interfere with the glycemic profile, such as insulin, cortisol, adrenocorticotrophic, epinephrine, glucagon, in addition to the GLUT4 protein activity; it is not measured in the intermediate phase of oxidative stress marker trainers, to confirm or at the exact time of adaptations of the antioxidant system. However, the findings open perspectives for further studies.

\section{COMPLIANCE WITH ETHICAL STANDARDS}

\section{Funding}

This research did not receive any specific grant from funding agencies in the public, commercial, or not-for-profit sectors. This study was funded by the authors

\section{Ethical approval}

This study was approved by the Ethics and Animal Research Committee of the Federal University of Sergipe under protocol 60/2017.

\section{Conflict of interest statement}

The authors have no conflict of interests to declare.

\section{Author Contributions}

Conceived and designed the experiments: WS, SSA. Performed the experiments: WS, SSA, JLS. Analyzed the data: WS, SSA, JLS, FJA, LMVS. Contributed reagents/materials/analysis tools: WS, SSA, JLS, ACM. Wrote the paper: WS, SSA, JLS, ACM, FJA, LMVS.

\section{REFERENCES}

1. Thompson WR. Worldwide survey of fitness trends for 2019: the CREP edition. Med Sci Sports Exerc: Health Fitness J 2018; 22(6): 10-17.

2. Batacan Jr RB, Duncand MJ, Dalboa VJ, Connolly KJ, Fenning AS. Light Intensity and High Intensity Interval Training Improve Cardiometabolic Health in Rats. Appl Physiol Nutr Metab 2016; 41(9): 945-52.

3. Cassidy S, Thoma C, Houghton D, Trenell M. High-intensity interval training: a review of its impact on glucose control and cardiometabolic health. Diabetologia 2017; 60:7-23.

4. Abe T, Kitaoka Y, Kikuchi DM, Takeda K, Numata O, Takemasa T. Highintensity interval training-induced metabolic adaptation coupled with an increase in Hif1alpha and glycolytic protein expression. J Appl Physiol 2015; 119(11):1297-302. 
5. Dos Santos JL, Dantas REA, Lima CA, De Araújo SS, De Almeida EC, Marçal $\mathrm{AC}$, et al. Protective effect of a hydroethanolic extract from Bowdichia virgilioides on muscular damage and oxidative stress caused by strenuous resistance training in rats. J Int Soc Sports Nutr 2014; 11(1):58.

6. Paraíso LF. Efeito do exercício físico na estabilidade de membrana de eritrócitos. [Tese de doutorado - Programa de Pós-Graduação em Genética e Bioquímica]. Uberlândia (MG): Universidade Federal de Uberlândia; 2015.

7. Souza LMV. Efeitos do treinamento intervalado de alta intensidade de curto prazo sobre os biomarcadores de estresse oxidativo e danos musculares em ratos. [Dissertação de Mestrado em Educação Física- Programa de Pós Graduação em Educação Física]. Sergipe (SE): Universidade Federal de Sergipe; 2018.

8. Marangon 1, Gobatto CA, Mello MAR, Kokubun E. Utilization of an hyperbolic model for the determination of the critical load in swimming rats. Med Sci Sports Exerc 2002; 34(5): S149.

9. Simões HG, Campbell CSG, Kokubun E, Denadai BS, Baldissera V. Determination of maximal lactate steady state velocity: coincidence with lower blood glucose. Med Sci Sports Exerc 1996; 28: S68-S77.

10. Simões HG. Comparação entre protocolos de determinação do limiar anaeróbio em testes de pista para corredores. [Dissertação de Mestrado em Ciências Fisiológicas - Centro de Ciências Biológicas e da Saúde]. São Paulo (SP): Universidade Federal de São Carlos. São Paulo; 1997.

11. Delevatti RS, Kanitz AC, Alberton CL, Marson EC, Pantoja PD, Pinho CDF, et al. Glycemic Threshold as an Alternative Method to Identify the Anaerobic Threshold in Patients With Type 2 Diabetes. Front Physiol 2018; 9:1609.

12. Gobatto FBM, Gobatto CA, Ribeiro C, Mota CSA, De Araújo GG, De Araújo $\mathrm{MB}$, et al. Limiar anaeróbio em corrida e natação para ratos: determinação utilizando dois métodos matemáticos. J Phys Educ 2010; 21(2): 245-253.

13. Pimenta M, Bringhenti I, Mello VS, Mendes IKS, Aguia MB, Lacerda CAM. High-intensity interval training beneficial effects on body mass, blood pressure, and oxidative stress in diet-induced obesity in ovariectomized mice. Life Science 2015; 139: 75-82.

14. Teixeira KR. Efeito das Proteínas do Soro do Leite no Estresse Oxidativo em Animais submetidos ao Exercício Físico de Alta Intensidade. [Dissertação de Mestrado - Programa de Pós-graduação em Saúde e Nutrição]. Minas Gerais (MG): Universidade Federal de Ouro Preto; 2013.

15. Freitas DA, Rocha-Vieira E, Soares BA, Nonato LF, Fonseca SR, Martins JB, et al. $\mathrm{O}$ treinamento intervalado de alta intensidade modula o estresse oxidativo hipocampal, o BDNF e os mediadores inflamatórios em ratos. Physiol Behav 2017; 184: 6-11.

16. Pereira VA, Silva DC, De Souza AR, De Almeida Filho EJB, Silva AS. Melhoria do estresse oxidativo em resposta a um programa de treinamento aeróbio é anterior à redução da glicemia. Anais do II Congresso Brasileiro de Ciências da Saúde 2017; Paraíba, Brasil. Available from: https://editorarealize.com.br/artigo/ visualizar/29413 [2017 oct 21].

17. Tromm CB, Da Rosa GL, Bom K, Mariano I, Poziz B, Tuon T, et al. Efeito de diferentes frequências semanais de treinamento sobre parâmetros de estresse oxidativo. Rev Bras Cineantropom Desempenho Hum 2012; 4(1):52-60.

18. Leite $\mathrm{CF}$, Rombaldi $\mathrm{AJ}$. Resposta renal à maltodextrina e ao treinamento em diferentes intensidades. Rev Bras CiêncEsporte 2015; 37(1):80-86.

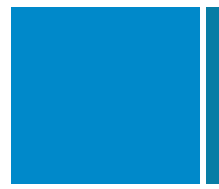

Corresponding author

Waleska dos Santos

Av. Juscelino Kubitscheck 66 A. New Town. Aracaju-Sergipe, Brasil

CEP: $49070-070$

E-mail: profa.msc.waleska@gmail.com 